\title{
Perbandingan Novel Raise the Red Lantern Karya Su Tong dan Film Raise the Red Lantern Karya Zhang Yimou dengan Pendekatan Ekranisasi
}

\author{
Ambar Widiawati ${ }^{1}$, Tri Budianingsih ${ }^{1}$, Sri Hartati ${ }^{1}$ \\ ${ }^{1}$ Program Studi Bahasa Mandarin dan Kebudayaan Tiongkok, Fakultas Ilmu Pengetahuan Budaya, \\ Universitas Al Azhar Indonesia, Jl. Sisingamangaraja No.2, RT.2/RW.1, Jakarta Selatan, 12110 \\ Penulis untuk korespondensi/Email: trixiaodi@gmail.com
}

\begin{abstract}
Raise the Red Lantern is one of Zhang Yimou's films adapted from Su Tong's Raise the Red Lantern novel. This novel and film tells the story of polygamy in Chinese society in the 1920s. Tells the story of the competition of 4 wives in fighting over the love and power of a wealthy master. The shift from the novel Raise the Red Lantern to the film Raise the Red Lantern causes the deletion, addition, and various changes in the intrinsic elements of the novel. These aspects are analyzed from data in the form of novels and films using the ecranisation approach. The goal is to find out the differences, similarities, and changes that occur as a result of the process of transferring vehicles from these two different material objects. The results of the analysis of the ecranisation of the novel Raise the Red Lantern into the film Raise the Red Lantern show that there are additions and deletions of events, alterations and deletions of settings, as well as replacement and removal of characters in the novel. However, the process of transferring vehicle does not change the outline of the story.
\end{abstract}

Abstract - Raise the Red Lantern merupakan salah satu film karya Zhang Yimou yang diadaptasi dari novel Raise the Red Lantern karya Su Tong. Novel dan film ini mengangkat kisah poligami di tengah masyarakat Tiongkok pada era 1920-an. Bercerita tentang persaingan 4 orang istri dalam memperebutkan cinta dan kekuasaan dari seorang Tuan Besar yang kaya raya. Alih wahana dari novel Raise the Red Lantern ke film Raise the Red Lantern menyebabkan terjadinya penciutan, penambahan, dan perubahan bervariasi pada unsur intrinsik novel. Pada tulisan ini aspek tersebut dianalisis dari data berupa novel dan film dengan menggunakan pendekatan ekranisasi. Tujuannya untuk mencari tahu perbedaan, persamaan, dan perubahan yang terjadi akibat proses alih wahana dari kedua objek material yang berbeda tersebut. Hasil analisis ekranisasi novel Raise the Red Lantern ke film Raise the Red Lantern menunjukkan adanya penambahan dan penghilangan peristiwa, pengubahan dan penghilangan latar, serta penggantian dan penghilangan tokoh dalam novel. Namun, proses alih wahana tidak mengubah garis besar cerita.

Keywords - novel, film, raise the Red Lantern, ecranisation.

\section{PENDAHULUAN}

$\mathrm{N}$ Tovel berasal dari bahasa latin novellus, diturunkan dari kata novies yang berarti baru. Sesuai dengan artinya, novel merupakan karya sastra yang paling baru dibandingkan puisi, drama, dan lainnya. Dalam The American College Dictionary, novel diartikan sebagai suatu cerita prosa yang fiktif dalam panjang tertentu yang melukiskan para tokoh, gerak serta adegan kehidupan yang representatif dalam suatu alur atau keadaan yang agak kacau dan kusut. [1] Secara luas prosa menyangkut semua karya tulis yang ditulis bukan dalam bentuk puisi atau drama, tiap baris dimulai dari margin kiri penuh sampai ke margin kanan. Dari segi jumlah kata, biasanya suatu novel berkisar antara 35.000 hingga tak terbatas jumlahnya. Seiring dengan perkembangan teknologi dan informasi, banyak novel yang 
kemudian diubah menjadi seni pertunjukan maupun film.

Film dalam bahasa Inggris disebut sebagai movie atau moving pictures 'gambar yang bergerak', merupakan salah satu jenis kesenian yang paling baru. Sesuai dengan namanya, film merupakan gambar bergerak yang ditonton di layar. Pada mulanya, film hanya berupa gambar bergerak hitam-putih tanpa suara (film bisu), kemudian berkembang menjadi gambar bergerak dengan aneka warna serta diimbuhi suara. [2]

Kegiatan mengubah media/wahana dalam suatu karya seni sudah berlangsung sejak zaman dahulu, contohnya seperti epos India Mahabharata dan Ramayana yang diterjemahkan ke dalam bahasa Jawa Kuno yang kemudian ditampilkan dalam bentuk kesenian lain seperti seni tari, drama, dan berbagai seni pertunjukan lain - terutama wayang kulit dan wayang boneka. [3] Kegiatan pengubahan wahana tersebut disebut sebagai alih wahana. Salah satu alih wahana yang banyak diminati masyarakat adalah ekranisasi, yakni pengubahan sebuah novel menjadi film.

Novel berjudul Wives and Concubine / Qi Qie Cheng Qun 《妻妾成群: Qī Qiè Chéng Qún》 (1990) karya Su Tong (苏童: SūTóng) merupakan salah satu novel asal Tiongkok yang dijadikan sebuah film oleh seorang sutradara terkenal Tiongkok bernama Zhang Yimou (张艺谋: Zhāng Yì Móu ) dengan judul Raise the Red Lantern yang dalam bahasa mandarin dikenal sebagai Da Hong Deng Long Gao Gao Gua 《大红灯笼高高挂: Dà Hóng Dēng Lóng Gāo Gāo Guà 》 (1991).

Su Tong adalah nama pena dari penulis asal Tiongkok bernama asli Tong Zhong Gui (童忠贵 Tóng Zhōng Guì) yang lahir di Suzhou (苏州 Sūzhōu ) pada 23 Januari 1963. Ia lulus dari Beijing Normal University (北京师范大学 Běijīng shīfàn dàxué) sebagai sarjana sastra Tiongkok dan menetap di Nanjing (南京 Nánjīng ). Su Tong diakui secara luas sebagai salah satu novelis terdepan Tiongkok. Ia dikenal sebagai penulis yang kontroversial karena menggunakan karyanya sebagai media kritik bagi pemerintah Tiongkok

Kepopuleran film Raise the Red Lantern mempengaruhi perubahan judul novel pada cetakan-cetakan selanjutnya yang juga menjadi Raise the Red Lantern. Judul tersebut diambil dari salah satu adegan dalam film, yakni pemasangan lampion merah di depan kediaman salah satu istri yang akan dikunjungi oleh Si Tuan Besar setiap malamnya. Film hasil ekranisasi ini menggambarkan kehidupan sebuah keluarga tradisional Tiongkok pada tahun 1920-an. Mengisahkan seorang gadis berusia 19 tahun bernama Songlian (颂莲: Sòng Lián) yang terpaksa meninggalkan perguruan tinggi setelah ayahnya meninggal dunia. Demi memenuhi ekonomi keluarganya, akhirnya Songlian menikah dengan laki-laki kaya dan menjadi istri keempatnya. Film ini merupakan salah satu film kontoversial yang dilarang beredar di Tiongkok karena dianggap sebagai upaya menyerang penguasa Tiongkok. Pemerintah Tiongkok menilai film ini merupakan bentuk kritik terhadap sistem pemerintahan, terutama dihubungkan dengan peristiwa Tiananmen pada tahun 1989.

Peristiwa Tiananmen adalah sebuah rangkaian demonstrasi yang dipimpin mahasiswa dan diadakan di Lapangan Tiananmen di Beijing antara 15 April hingga 4 Juni 1989. Protes ini ditujukan terhadap ketidakstabilan ekonomi dan korupsi politik yang kemudian merembet menjadi demonstrasi pro-demokrasi yang merupakan suatu hal yang belum lazim di Tiongkok yang otoriter. Lebih dari 3000 orang meninggal akibat tindakan dari pasukan bersenjata

\section{STRUKTUR FIKSI DAN ALIH WAHANA}

\section{Struktur Fiksi}

Teori struktural sastra menekankan keseluruhan relasi antar berbagai unsur pembangunnya. Novel sebagai salah satu jenis karya sastra pun memiliki hal yang sama. Unsur pembangun novel menjadi 3 bagian, yakni fakta cerita, tema, dan sarana pengucapan. Fakta dalam sebuah cerita meliputi karakter (tokoh cerita), alur, dan latar. Ketiganya merupakan unsur fiksi yang secara faktual dapat dibayangkan peristiwanya dalam sebuah novel.Tema merupakan dasar cerita atau inti persoalan yang hendak dikemukakan kepada pembaca yang berkaitan dengan berbagai pengalaman hidup manusia, seperti percintaan, ketuhanan, pertemanan, dan lain sebagainya. Kemudian sarana pengucapan sastra adalah teknik pengarang untuk memilih dan menyusun detaildetail cerita menjadi pola yang bermakna. Jenis sarana kesusastraan yang dimaksud antara lain berupa gaya bahasa dan nada, sudut pandang penceritaan, simbolisme, dan ironi (sindiran halus). [4]. Pada penelitian ini, penulis menekankan 
pembahasan pada fakta cerita, yakni alur, latar, dan karakter (tokoh cerita).

$\underline{\text { Alur }}$

Alur mengandung unsur urutan waktu, baik yang dikemukakan secara eksplisit maupun implisit. Urutan waktu yang dimaksud adalah waktu terjadinya peristiwa-peristiwa yang diceritakan pada fiksi yang bersangkutan. Pada permulaan, biasanya pengarang memperkenalkan tokohtokohnya. Tokoh yang satu dihubungkan dengan tokoh lainnnya. Dari perhubungan ini akan terjadi berbagai persoalan, yang makin lama makin memuncak. Kemudian cerita melaju pada peleraian. Tokoh-tokoh dalam cerita menempuh jalan atau sikap sendiri-sendiri, sampai pada suatu akhir cerita.

\section{Latar}

Sebuah kejadian tentu saja terjadi pada suatu ruang, tempat, dan kurun waktu tertentu. Latar berusaha menerangkan apakah kejadian itu terjadi di rumah, di stasiun kereta api, di desa, di kota, di hutan atau di tempat lain. Latar juga dapat menjelaskan apakah peristiwa itu berlangsung pada pagi hari, siang hari, malam hari, subuh tau waktu yang lain. Latar juga menerangkan apakah kejadian itu terjadi pada zaman penjajahan, zaman merdeka, zaman dinasti, zaman orde lama, zaman orde baru atau zaman lain. Kemudian bagaimana keadaan pada zaman yang digambarkan itu, siapa yang memerintah, dan seterusnya. Pendek kata, latar adalah tempat berpijak atau bertumpunya cerita, alur, dan tokohtokoh novel. [5]

\section{Tokoh dan Penokohan}

Dalam cerita fiksi biasanya terdapat istilah-istilah seperti tokoh dan penokohan, watak dan perwatakan, atau karakter dan karakterisasi yang secara bergantian menunjuk pengertian yang hampir sama. Istilah tokoh menunjuk pada orangnya, pelaku cerita. Sedangkan penokohan menunjuk pada sifat dan sikap para tokoh seperti yang ditafsirkan para pembaca, menunjuk pada kualitas pribadi seorang tokoh.[4] Melalui sifat dan watak yang dimiliki tokoh-tokoh novel, pembaca dapat mengerti kenapa suatu tindakan atau kejadian dapat terjadi, karena watak yang dimiliki seseorang merupakan motivasi untuk kejadian-kejadian atau peristiwa-peristiwa selanjutnya yang terjalin dalam alur cerita.

\section{Alih Wahana}

Alih wahana mencakup kegiatan penerjemahan, penyaduran, dan pemindahan dari satu jenis kesenian ke jenis kesenian lain. Wahana berarti kendaraan, jadi alih wahana adalah proses pengalihan dari satu jenis 'kendaraan' ke jenis 'kendaraan' lain. Sebagai 'kendaraan', suatu karya seni merupakan alat yang bisa mengalihkan sesuatu dari satu tempat ke tempat lain. Wahana diartikan juga sebagai medium yang dipergunakan untuk mengungkapkan, mencapai, atau memamerkan gagasan atau perasaan. Dalam arti yang lebih luas, istilah ini bahkan juga bisa mencakup pengubahan dari berbagai jenis ilmu pengetahuan menjadi karya seni. [2]

\section{Ekranisasi}

Ekranisasi adalah pelayarputihan atau pemindahan sebuah novel ke dalam film. Istilah ekranisasi sendiri berasal dari bahasa Perancis, yakni ecran, yang berarti layar. Pemindahan novel ke layar putih mau tidak mau mengakibatkan timbulnya berbagai perubahan. Novel adalah kreasi individual dan merupakan hasil kerja perseorangan. Seseorang yang mempuyai pengalaman, pemikiran, ide, atau hal lain dapat saja menuliskannya di atas kertas dan jadilah sebuah novel yang siap dibaca. Tidak demikian dengan pembuatan film. Film merupakan hasil kerja gotong-royong. Bagus-tidaknya sebuah film, banyak bergantung pada keharmonisan kerja unit-unit di dalamnya, seperti produser, penulis skenario, sutradara, juru kamera, penata artistik, perekam suara, para pemain, dan lain-lain. [5] Ekranisasi mengakibatkan penciutan, penambahan, dan perubahan bervariasi dari novel aslinya.

\section{Penciutan}

Ekranisasi membuat novel yang dibaca selama berjam-jam bahkan berhari-hari menjadi sebuah tayangan yang hanya berdurasi sekitar 1 sampai 2 jam. Dengan kata lain, novel yang tebal harus mengalami pemotongan atau penciutan bila akan difilmkan. Hal itu mengindikasikan bahwa tidak semua hal yang diungkapkan dalam novel akan dijumpai pula dalam film. Sebagian cerita, tokoh, latar maupun unsur lainnya tidak akan ditemui dalam film. Hal ini dikarenakan pembuat film (penulis skenario dan sutradara) telah memilih bagian-bagian atau informasi-informasi yang dianggap penting untuk ditampilkan.

\section{Penambahan}

Penambahan terjadi karena penulis skenario dan sutradara telah menafsirkan terlebih dahulu novel yang hendak difilmkan sehingga akan terjadi penambahan, misalnya penambahan pada cerita, alur, penokohan, atau latarnya. Dalam proses ekranisiasi, tidak sedikit adegan dalam novel tidak ditampilkan tapi dalam film ditampilkan. Latar pun 
juga tidak luput dari adanya penambahan, dalam film seringkali dijumpai adanya latar yang ditampilkan tetapi dalam novel tidak ditampilkan. Demikian juga dengan tokoh, karena alasan filmis (istilah yang menyangkut segala sesuatu yang berhubungan dengan film) ataupun lainnya seorang penulis skenario dan sutradara bisa menambahkan tokoh baru yang tidak disebutkan dalam novel. Sama halnya seperti penciutan, seorang sutradara tentu memilki alasan tertentu untuk melakukan berbagai penambahan ini, misalnya karena penting dari sudut filmis, penambahan karena masih relevan dengan cerita keseluruhan, maupun karena berbagai alasan lain yang bertujuan untuk menarik minat penonton. [5]

\section{Perubahan Bervariasi}

Selain adanya penciutan dan penambahan. Proses ekranisasi juga memungkinkan terjadinya variasivariasi tertentu dalam film. Walaupun terjadi variasi-variasi antara novel dan film, namun pada hakikatnya tema/amanat novel masih akan terungkap dalam film, karena perbedaan alat-alat yang digunakan, terjadilah variasi-variasi tertentu di beberapa bagian unsur-unsur intrinsiknya. Di samping itu, pemutaran film memilki waktu yang terbatas sehingga variasi yang disuguhkan dalam film diharapkan mampu untuk memikat penonton dan membuatnya tidak bosan untuk menonton filmnya hingga akhir. [5]

\section{Ekranisasi di Tiongkok}

Film pertama kali diputar di Tiongkok oleh seorang pengusaha Spanyol bernama Galen Bocca pada tanggal 11 Agustus 1896. Pada awalnya, film-film yang diputar di Tiongkok ditonton di kedai-kedai teh atau tenda-tenda yang didirikan di luar ruangan. Sampai akhirnya ada gedung teater yang nyaman di Shanghai (上海 Shànghăi) pada akhir tahun 1920an. [6]

Pada 1906, Studio Fotografi Fengtai Beijing (北京 丰泰照相馆 Běijīnng Fēngtài Zhàoxiàng Guăn) memfilmkan sebuah serial berjudul Dingjun Mountain ( 定 军山 Dìngjūn Shān) yang menggambarkan adegan-adegan dalam opera Beijing, hal ini menandai awal pembuatan film di Tiongkok. Sementara itu, Suffering Husband and Wife (难夫难亲 Nán fū nán qīn) yang disutradarai oleh Zheng Zhengqiu（郑正秋 Zhèng Zhèngqiū) dan Zhang Shichuan (张石川 Zhāng Shíchuān) pada 1913 merupakan film Tiongkok yang pertama [7].
Film-film yang disutradarai oleh Zhang Yimou adalah salah satu contoh produk ekranisasi yang terkenal sekaligus kontroversial di Tiongkok. Zhang Yimou dikenal sebagai sinematografer yang handal dalam bermain simbol untuk memberi kritik terhadap pemerintah Tiongkok yang membuat beberapa film garapannya dilarang beredar di Tiongkok. Film-film tersebut antara lain yakni Red Shorgum (红高粱 Hóng Gāoliáng) yang dirilis pada tahun 1987. Film ini diadaptasi dari novel karya Mo Yan (莫言 Mò Yán) yang berjudul Red Shorgum Clan (红高粱家族 Hóng Gāo Liáng Jiā Zú) yang diterbitkan pada tahun 1986. Novel dan film ini mengisahkan tentang kehidupan seorang wanita muda di penyulingan minuman keras sorgum (Sorgum adalah tanaman serbaguna yang dapat digunakan sebagai sumber pangan, pakan ternak dan bahan baku industri. Sebagai bahan pangan, sorgum berada pada urutan ke-5 setelah gandum, jagung, padi, dan jelai). Selain film tersebut, ada juga film To Live (活着 Huózhe) pada tahun 1994 yang diadaptasi dari novel dengan judul yang sama karangan Yu Hua (余华 Yú Huá) yang dirilis pada tahun 1995 .

\section{PERBANDINGAN NOVEL RAISE THE RED LANTERN DAN FILM RAISE THE RED LANTERN}

\section{Sinopsis Novel Raise the Red Lantern Dan Film Raise the Red Lantern}

Secara garis besar, novel dan film Raise the Red Lantern memiliki tema dan cerita yang sama, yakni seputar pernikahan yang mengisahkan tentang seorang gadis muda bernama Songlian yang terpaksa menjadi istri keempat seorang Tuan Besar kaya raya bernama Chen Zuoqian demi memenuhi kebutuhan ekonomi keluarganya. Songlian dan ketiga istri Chen Zuoqian yang lain saling bersaing agar mendapatkan kasih sayang dan posisi yang kuat dalam rumah tangga, mereka pun terlibat dalam persaingan yang tidak sehat. Persaingan tidak sehat ini dikarenakan sistem poligami yang terjadi dalam keluarga patriarki menempatkan banyak wanita dalam satu lingkungan yang sama. Dampak dari persaingan antar istri tersebut mengakibatkan hal-hal tragis berupa meninggalnya istri ketiga Chen Zuoqian dan tokoh utama yakni Songlian yang menjadi gila. Dikarenakan penerjemahan novel ke bahasa Indonesia, terdapat beberapa nama tokoh yang berubah. Penulis akan menulis nama-nama tokoh versi novel jika sedang membahas novel dan akan menulis nama-nama 
tokoh versi film jika sedang membahas film. Namanama tokoh yang berubah tersebut yakni Songlian (颂莲: Sòng Lián) menjadi Teratai, Yuru (艈如: Yù Rú) menjadi Sukacita, Zhuoyun (卓云: Zhuō Yún) menjadi Mega, Meishan menjadi Karang (梅珊: Méi Shān), dan Yan'er (雁儿: Yàn Er) menjadi Walet.

\section{Perbandingan Struktur Novel Raise the Red Lantern dan Film Raise the Red Lantern}

Proses ekranisasi menyebabkan perubahan struktur penceritaan. Baik dari segi alur, tokoh dan penokohan, maupun latar yang mencakup latar tempat, latar waktu dan latar sosial budaya. Hal ini wajar terjadi mengingat tidak semua hal di dalam novel bisa difilmkan dan tergantung kreativitas masing-masing sutradara untuk membuat filmnya menjadi bahan yang menarik untuk ditonton.

\section{Perbandingan Alur}

Terdapat perbedaan alur antara novel dan film Raise the Red Lantern. Perbedaan tersebut berupa perubahan dan penambahan adegan. Berikut ini tabel perbandingan alur antara novel dan film Raise the Red Lantern.

Tabel 1: Tabel Perbandingan Aspek Alur Novel dan Film Raise the Red Lantern

\begin{tabular}{|c|c|c|c|}
\hline No & Aspek Alur & Novel & Film \\
\hline 1. & Pembuka/ awal cerita & $\begin{array}{l}\text { Penggambaran Teratai } \\
\text { saat pertama kali datang } \\
\text { ke kediaman keluarga } \\
\text { Chen. }\end{array}$ & $\begin{array}{l}\text { Film memvisualisasikan } \\
\text { adegan Songlian yang sedang } \\
\text { berbicara dengan ibu tirinya } \\
\text { menegenai keputusannya } \\
\text { untuk menikah dengan pria } \\
\text { kaya. }\end{array}$ \\
\hline 2. & $\begin{array}{l}\text { Tengah: } \\
\text { a. Konflik }\end{array}$ & $\begin{array}{l}\text { Tuan Chen } \\
\text { memperkenalkan Teratai } \\
\text { kepada istri-istrinya yang } \\
\text { lain dan menimbulkan } \\
\text { kecemburuan di antara } \\
\text { mereka. }\end{array}$ & $\begin{array}{l}\text { Film memvisualiasikan } \\
\text { adegan konflik ketika salah } \\
\text { satu pelayan kepercayaan } \\
\text { Chen Zuoqian } \\
\text { memperkenalkan Songlian } \\
\text { kepada istri-istri Chen yang } \\
\text { lain, hal ini menumbuhkan } \\
\text { kecemburuan di antara } \\
\text { mereka. }\end{array}$ \\
\hline & b.Komplikasi & $\begin{array}{l}\text { Teratai mengetahui } \\
\text { perselingkuhan antara } \\
\text { Karang dan Doker Gao. } \\
\text { Teratai menemukan } \\
\text { boneka guna-guna yang } \\
\text { ditujukan dirinya di } \\
\text { kamar Walet dan orang } \\
\text { yang menulis nama } \\
\text { Teratai di boneka santet } \\
\text { tersebut adalah Mega. } \\
\text { Novel tidak menceritakan } \\
\text { Teratai yang berpura-pura } \\
\text { hamil. } \\
\text { Walet meninggal karena } \\
\text { sakit tifus. }\end{array}$ & $\begin{array}{l}\text { Songlian mengetahui Meishan } \\
\text { dan Dokter Gao memilki } \\
\text { hubungan terlarang. } \\
\text { Film memvisualisasi-kan } \\
\text { adegan Songlian yang } \\
\text { menemukan boneka guna- } \\
\text { guna di kamar Yan'er. } \\
\text { Setelah menginterogasi-nya, } \\
\text { Yan'er mengaku bahwa } \\
\text { Zhuoyun lah yang menulis } \\
\text { nama Songlian di boneka } \\
\text { santet tersebut. } \\
\text { Songlian berpura-pura hamil } \\
\text { dan akhirnya kebohongannya } \\
\text { diketahui oleh Chen Zuoqian. }\end{array}$ \\
\hline & c.Klimaks & $\begin{array}{l}\text { Novel tidak menceritakan } \\
\text { adegan Songlian yang } \\
\text { tidak sengaja } \\
\text { membeberkan } \\
\text { perselingkuhan karang } \\
\text { dan Dokter Gao } \\
\text { Karang dihukum dengan } \\
\text { diceburkan kedalam }\end{array}$ & $\begin{array}{l}\text { Yan'er meninggal setelah } \\
\text { dihukum Songlian untuk } \\
\text { berlutut di tengah hujan salju } \\
\text { Songlian tidak sengaja } \\
\text { membeberkan perselingkuhan } \\
\text { Meishan dan Dokter Gao saat } \\
\text { mabuk. } \\
\text { Meishan dihukum gantung. }\end{array}$ \\
\hline
\end{tabular}

Tidak terdapat perbedaan alur konflik antara novel dan film, hanya terdapat perbedaan pada tokoh yang memperkenalkan Songlian kepada istri-istri Tuan Chen.

Terdapat perbedaan alur komplikasi antara novel dan film, yakni berupa perubahan dan penambahan alur. 


\begin{tabular}{cclll}
\hline No & \multicolumn{1}{c}{ Aspek Alur } & \multicolumn{1}{c}{ Novel } & \multicolumn{1}{c}{ Film } & \multicolumn{1}{c}{ Hasil Perbandingan } \\
\hline 3. & Akhir/ penyelesaian & $\begin{array}{l}\text { Songlian kehilangan } \\
\text { akalnya/gila. } \\
\text { Tuan Chen menikah lagi } \\
\text { dengan istri kelimanya. }\end{array}$ & $\begin{array}{l}\text { Songlian menjadi gila } \\
\text { Tuan Chen menikah dengan } \\
\text { istri kelimanya. }\end{array}$ & $\begin{array}{l}\text { Terdapat persamaan alur akhir } \\
\text { antara novel dan film. }\end{array}$ \\
& & & \\
& & & \\
& &
\end{tabular}

\section{Perbandingan Latar}

Latar merupakan salah satu unsur yang sangat penting dalam sebuah fiksi. Latar memberikan tumpuan mengenai keadaan lingkungan tempat berlangsungnya peristiwa-peristiwa yang diceritakan dalam sebuah fiksi. Latar mencakup aspek tempat, waktu, dan lingkungan sosial. Dalam peneltian ini penulis hanya akan membahas unsur intrinsik, sehingga pembahasan hanya mencakup latar tempat dan latar waktu.

\section{Latar Tempat}

Latar tempat berlangsungnya peristiwa yang ditampilkan di dalam novel Raise the Red Lantern sebagian besar hanya berkisar di kediaman Chen, oleh karena itu peristiwa-peristiwa dalam novel ini hanya terjadi di bagian-bagian rumah kediaman keluarga Chen, kecuali rumah keluarga Songlian dan Restoran Barat. Bagian-bagian rumah tersebut antara lain seperti kamar, toilet, taman, dan ruang tamu. Dalam film Raise the Red Lantern, latar yang ditampilkan tidak jauh berbeda dengan latar yang digambarkan dalam novel, hanya saja ada beberapa latar tempat dihilangkan atau diganti. Berikut tabel perbandingan latar tempat antara novel Raise the Red Lantern dengan film Raise the Red Lantern.

Tabel 2: Tabel Perbandingan Latar Tempat antara Novel dan Film Raise the Red Lantern

\begin{tabular}{|c|c|c|c|}
\hline Nama Tempat & Novel & Film & Hasil Perbandingan \\
\hline Restoran Barat & $\begin{array}{l}\text { Atas permintaan Teratai, Chen Zuoqian } \\
\text { menemui Teratai untuk pertama kalinya di } \\
\text { sebuah Restoran Barat. }\end{array}$ & Tidak diceritakan & $\begin{array}{l}\text { Terdapat perbedaan pada } \\
\text { beberapa latar tempat, } \\
\text { baik yang dihilangkan } \\
\text { maupun diganti dengan }\end{array}$ \\
\hline $\begin{array}{l}\text { Rumah orangtua Teratai/ } \\
\text { Songlian }\end{array}$ & $\begin{array}{l}\text { Teratai kembali ke rumah setelah berhenti } \\
\text { kuliah dan menemukan ayahnya bunuh diri } \\
\text { di dapur. Tidak berselang lama setelah } \\
\text { peristiwa tersebut, Songlian dan ibu tirinya } \\
\text { membahas mengenai rencana pernikahan } \\
\text { Songlian dengan seorang pria kaya raya } \\
\text { yang memiliki banyak istri. }\end{array}$ & $\begin{array}{l}\text { Film hanya } \\
\text { memvisulisasikan } \\
\text { adegan percakapan } \\
\text { antara Songlian dan ibu } \\
\text { tirinya perihal } \\
\text { pernikahan Songlian. } \\
\text { Tidak ditampilkan } \\
\text { mengenai peristiwa } \\
\text { bunuh diri ayah } \\
\text { Songlian. }\end{array}$ & tempat lain. \\
\hline Toilet & $\begin{array}{l}\text { Teratai menemukan kertas toilet berisi } \\
\text { guna-guna yang ditujukan kepada dirinya. } \\
\text { Kertas toilet tersebut masih mengapung di } \\
\text { toilet. }\end{array}$ & Tidak diceritakan & \\
\hline $\begin{array}{l}\text { Ruangan kecil di atap } \\
\text { dan Sumur }\end{array}$ & $\begin{array}{l}\text { Karang dihukum dengan diceburkan ke } \\
\text { sumur setelah perselingkuhannya dengan } \\
\text { seorang dokter terbongkar. }\end{array}$ & $\begin{array}{l}\text { Meishan dihukum } \\
\text { gantung di sebuah } \\
\text { ruangan kecil di atap } \\
\text { kediaman Chen atas } \\
\text { perselingkuhannya } \\
\text { dengan Dokter Gao. }\end{array}$ & \\
\hline Kamar Walet/ Yan'er & $\begin{array}{l}\text { Teratai curiga serulingnya dicuri oleh } \\
\text { Walet, sehingga ia datang ke kamar Walet } \\
\text { untuk memeriksanya dan menemukan } \\
\text { boneka guna-guna yang ditujukan kepada } \\
\text { dirinya. }\end{array}$ & $\begin{array}{l}\text { Songlian memeriksa } \\
\text { kamar Yan'er karena } \\
\text { curiga Yan'er } \\
\text { mengambil serulingnya. } \\
\text { Namun, dirinya malah } \\
\text { menemukan sebuah } \\
\text { boneka guna-guna untuk } \\
\text { dirinya. }\end{array}$ & \\
\hline $\begin{array}{l}\text { Kapel Buddha dan } \\
\text { Kamar Sukacita/ Yuru }\end{array}$ & $\begin{array}{l}\text { Sukacita sedang berada di kapel Buddha } \\
\text { saat Chen memperkenalkan Teratai } \\
\text { kepadanya. }\end{array}$ & $\begin{array}{l}\text { Songlian diantar seorang } \\
\text { pelayan laki-laki tua } \\
\text { mengunjungi kamar }\end{array}$ & \\
\hline
\end{tabular}




\begin{tabular}{|c|c|c|c|}
\hline Nama Tempat & Novel & Film & Hasil Perbandingan \\
\hline & & $\begin{array}{l}\text { Yuru untuk } \\
\text { memperkenalkan diri } \\
\text { sebagai istri keempat } \\
\text { Chen Zuoqian. }\end{array}$ & \\
\hline Kamar Karang/ Meishan & $\begin{array}{l}\text { Karang bermain mahyong di kamarnya } \\
\text { bersama dengan Songlian dan } 2 \text { laki-laki, } \\
\text { yakni seorang pelayan di kediaman Chen } \\
\text { dan seorang dokter. }\end{array}$ & $\begin{array}{l}\text { Meishan mengundang } \\
\text { Songlian untuk bermain } \\
\text { mahyong di kamarnya } \\
\text { bersama dengan Dokter } \\
\text { Gao dan teman laki- } \\
\text { lakinya. }\end{array}$ & \\
\hline Kamar Teratai/ Songlian & $\begin{array}{l}\text { Mega datang ke kamar Teratai meminta } \\
\text { bantuan untuk memotongkan rambutnya. }\end{array}$ & $\begin{array}{l}\text { Zhuoyun mendatangi } \\
\text { kamar Songlian, } \\
\text { meminta untuk } \\
\text { memotong rambutnya. }\end{array}$ & \\
\hline Ruang tamu & $\begin{array}{l}\text { Chen Zuoqian merayakan hari ulang } \\
\text { tahunnya yang ke- } 50 \text { dan menerima tamu } \\
\text { undangannya di ruang tamu. }\end{array}$ & $\begin{array}{l}\text { Dokter Gao menjelaskan } \\
\text { hasil pemeriksaan } \\
\text { kehamilan Songlian } \\
\text { kepada Chen Zuoqian. }\end{array}$ & \\
\hline
\end{tabular}

\section{Latar Waktu}

Latar waktu yang digambarkan Su Tong dalam novel Raise the Red Lantern mengalami perubahan yang cukup besar saat dijadikan film Raise the Red Lantern oleh Zhang Yimou. Hal ini bisa dilihat dari pembagian alur cerita berdasarkan musim yang berlangsung. Perbedaan musim antara novel dan film terjadi sejak awal hingga akhir cerita. Berikut tabel perbandigan latar waktu antara novel Raise the Red Lantern dengan film Raise the Red Lantern.

Tabel 3. Tabel Perbandingan Latar Waktu antara Novel dan Film Raise the Red Lantern

\begin{tabular}{|c|c|c|c|c|}
\hline \multicolumn{2}{|r|}{ Novel } & \multicolumn{2}{|r|}{ Film } & \multirow{2}{*}{\begin{tabular}{l}
\multicolumn{1}{c}{ Hasil } \\
Perbandingan \\
Terdapat \\
perbedaan \\
latar waktu \\
antara novel \\
dan film.
\end{tabular}} \\
\hline $\begin{array}{l}\text { Musim } \\
\text { gugur }\end{array}$ & $\begin{array}{l}\text { Teratai pertama kalinya } \\
\text { datang ke kediaman Chen } \\
\text { dan menyandang status } \\
\text { sebagai Istri Keempat Chen } \\
\text { Zuoqian. Teratai mendapat } \\
\text { perhatian yang lebih } \\
\text { dibandingkan dengan istri- } \\
\text { istri lain sehingga mereka } \\
\text { saling menjatuhkan satu } \\
\text { sama lain demi menarik } \\
\text { perhatian Chen Zuoqian. }\end{array}$ & Musim panas & $\begin{array}{l}\text { Pertama kalinya Songlian menginjakkan } \\
\text { kaki di kediaman Chen dan menjadi istri } \\
\text { Chen Zuoqian. Sebagai istri baru, Songlian } \\
\text { mendapatkan perhatian yang lebih dari } \\
\text { Chen Zuoqian. }\end{array}$ & \\
\hline $\begin{array}{l}\text { Musim } \\
\text { dingin }\end{array}$ & $\begin{array}{l}\text { Keempat istri Chen Zuoqian } \\
\text { mengkhawatirkan Chen } \\
\text { Zuoqian yang mulai } \\
\text { impoten. Namun, Mega } \\
\text { berhasil mengatasinya dan } \\
\text { membuat Chen Zuoqian } \\
\text { sering berkunjung ke } \\
\text { kamarnya. }\end{array}$ & Musim gugur & $\begin{array}{l}\text { Istri-istri Chen Zuoqian yang lain merasa iri } \\
\text { dengan perlakuan istimewa yang diberikan } \\
\text { Chen Zuoqian kepada Songlian. Mereka } \\
\text { masing-masing mengatur startegi untuk } \\
\text { saling menjatuhkan dan Songlian berpura- } \\
\text { pura hamil. }\end{array}$ & \\
\hline \multirow[t]{2}{*}{$\begin{array}{l}\text { Musim } \\
\text { semi tahun } \\
\text { berikutnya }\end{array}$} & $\begin{array}{l}\text { Chen Zuoqian menikah } \\
\text { dengan istri kelimanya, } \\
\text { yakni Bambu dan Songlian } \\
\text { kehilangan akal sehatnya. }\end{array}$ & Musim dingin & $\begin{array}{l}\text { Songlian ketahuan berbohong tentang } \\
\text { kehamilannnya. Chen Zuoqian marah besar } \\
\text { kepadanya. Songlian mecurigai Yan'er lah } \\
\text { yang telah membocorkan rahasianya dan } \\
\text { menghukumnya hingga ia jatuh sakit dan } \\
\text { akhirnya meninggal dunia. Meishan juga } \\
\text { meninggal dunia dengan dihukum gantung } \\
\text { karena berselingkuh. }\end{array}$ & \\
\hline & & $\begin{array}{l}\text { Musim panas } \\
\text { tahun berikutnya }\end{array}$ & $\begin{array}{l}\text { Chen Zuoqian mengambil seorang gadis } \\
\text { untuk dijadikan istri kelimanya dan } \\
\text { Songlian kehilangan akal sehatnya. }\end{array}$ & \\
\hline
\end{tabular}




\section{Perbandingan Tokoh dan Penokohan}

Ada beberapa tokoh film Raise the Red Lantern yang karakternya tidak sepenuhnya sama dengan yang digambarkan dalam novel, bahkan ada pula tokoh yang dihilangkan. Berikut merupakan tabel perbandingannya.

Tabel 4: Tabel Perbandingan Tokoh Penokohan antara Novel dan Film Raise the Red Lantern

\begin{tabular}{|c|c|c|c|}
\hline Aspek Tokoh & Novel & Film & Hasil Perbandingan \\
\hline $\begin{array}{l}\text { Karakter tokoh: } \\
\text { a. Teratai/ Songlian } \\
\text { b.Chen Zuoqian }\end{array}$ & $\begin{array}{l}\text { Teratai digambarkan sebagai } \\
\text { wanita yang cantik, } \\
\text { berpendidikan, keras kepala. } \\
\text { Novel menggambarkan Chen } \\
\text { sebagai sosok yang hiperseks, } \\
\text { pencemburu, da tidak } \\
\text { menghargai wanita. }\end{array}$ & $\begin{array}{l}\text { Songlian digambarkan sebagai } \\
\text { karakter wanita yang kuat dan } \\
\text { berpendidikan, cantik, namun agak } \\
\text { ceroboh. } \\
\text { Karakter Chen memilki pengaruh } \\
\text { yang sangat kuat di dalam rumah } \\
\text { tangganya, pencemburu, serta gemar } \\
\text { mencumbui wanita lain yang bukan } \\
\text { istrinya. }\end{array}$ & $\begin{array}{l}\text { Terdapat perbedaan } \\
\text { karakter dan } \\
\text { penghilangan tokoh. }\end{array}$ \\
\hline c. Sukacita/ Yuru & $\begin{array}{l}\text { Sukacita memilki karakter } \\
\text { religius, tegas, dan sedikit } \\
\text { kasar. }\end{array}$ & $\begin{array}{l}\text { Yuru digambarkan sebagai sosok } \\
\text { religius, tegas dan netral. }\end{array}$ & \\
\hline d. Mega/ Zhuoyun & $\begin{array}{l}\text { Mega digambarkan memilki } \\
\text { sifat jahat, licik, dan haus } \\
\text { kekuasaan. }\end{array}$ & $\begin{array}{l}\text { Zhuoyun memilki karakter yang licik } \\
\text { serta haus perhatian dan kekuasaan. }\end{array}$ & \\
\hline e. Karang/ Meishan & $\begin{array}{l}\text { Karang digambarkan sebagai } \\
\text { sosok yang cantik, anggun, } \\
\text { pandai menyanyi opera, namun } \\
\text { tidak setia. }\end{array}$ & $\begin{array}{l}\text { Meishan digambarkan sebagai sosok } \\
\text { yang pandai menyanyi opera dan } \\
\text { cantik, namun tidak setia. }\end{array}$ & \\
\hline f. Walet/Yan'er & $\begin{array}{l}\text { Walet memilki sifat } \\
\text { pendendam, licik, dan tidak } \\
\text { ramah. }\end{array}$ & $\begin{array}{l}\text { Yan'er bersifat licik, pendendam, dan } \\
\text { selalu memasang wajah muram. }\end{array}$ & \\
\hline g. Feipu & $\begin{array}{l}\text { Novel menggambarkan Feipu } \\
\text { sebagai tokoh yang ramah, agak } \\
\text { takutterhadap wanita dan } \\
\text { memiliki ketertarikan khusus } \\
\text { kepada laki-laki. }\end{array}$ & $\begin{array}{l}\text { Film menggambarkan sosok Feipu } \\
\text { sebagai sosok yang baik, ramah, } \\
\text { namun tidak setia kawan. } \\
\text { Film menggambarkan Dokter Gao } \\
\text { sebagai sosok yang ramah, senang } \\
\text { memuji, namun pengkhianat. }\end{array}$ & \\
\hline h. Dokter Gao & $\begin{array}{l}\text { Dokter Gao digambarkan } \\
\text { sebagai sosok pengkhianat. }\end{array}$ & Tidak diceritakan & \\
\hline $\begin{array}{l}\text { i. Pemuda Ketiga Gu/ } \\
\text { Tuan Muda Gu }\end{array}$ & $\begin{array}{l}\text { Novel menggambarkan Tuan } \\
\text { Muda Gu sebagai sosok yang } \\
\text { pandai bermain seruling, sedikit } \\
\text { pemalu, dan takut terhadap } \\
\text { wanita. }\end{array}$ & & \\
\hline
\end{tabular}

\section{Ekranisasi Novel Raise the Red Lantern ke Film} Raise the Red Lantern

Proses ekranisasi menyebabkan berbagai perubahan antara novel dan filmnya. Perubahan yang terjadi dalam ekranisasi dapat berupa penciutan, penambahan, serta perubahan bervariasi. Hal ini dikarenakan keterbatasan waktu dalam film, proses kreatif para pembuat film, strategi untuk menarik minat penonton, maupun alasan filmis lainnya. Walau begitu, perubahan yang terjadi dalam proses ekranisasi tidak akan merubah inti cerita dari suatu novel itu sendiri.

\section{$\underline{\text { Penciutan }}$}

Penciutan banyak terjadi dalam penulisan latar tempat. Hal ini pun akhirnya berdampak pada berkurangnya peristiwa. Selain itu, terdapat pula penciutan/penghilangan tokoh dalam novel. Penghilangan tokoh novel ini adalah hal yang wajar apabila tokoh dalam novel dianggap tidak terlalu memilki peranan yang penting. Berbagai penciutan ini dilakukan karena keterbatasan waktu film, 
sehingga tidak memungkinkan untuk memasukkan seluruh isi novel ke dalam film. Namun penghilangan yang terjadi dalam film tidak mengakibatkan substansi film Raise the Red
Lantern keluar jauh dari cerita novelnya. Berikut tabel yang menunjukkan penciutan novel Raise the Red Lantern ke film Raise the Red Lantern.

Tabel 5. Tabel Penciutan novel Raise the Red Lantern ke film Raise the Red Lantern

\begin{tabular}{|c|c|c|}
\hline Peristiwa & Novel & Film \\
\hline Karakter tokoh Feipu. & $\begin{array}{l}\text { Feipu digambarkan sebagai sosok yang agak takut } \\
\text { terhadap wanita dan memiliki ketertarikan khusus } \\
\text { kepada laki-laki. (Su Tong, diterjemahkan oleh } \\
\text { Rasmani Astuti, 2011:83) }\end{array}$ & Tidak diceritakan \\
\hline Chen Zuoqian impoten. & $\begin{array}{l}\text { Memasuki musim dingin saat usianya telah } \\
\text { menginjak } 50 \text { tahun, kemampuan seksual Chen } \\
\text { Zuoqian menurun. (Su Tong, diterjemahkan oleh } \\
\text { Rasmani Astuti, 2011:63) }\end{array}$ & Tidak diceritakan \\
\hline Latar toilet. & $\begin{array}{l}\text { Walet menemukan kertas guna-guna bergambar } \\
\text { dirinya di toilet. (Su Tong, diterjemahkan oleh } \\
\text { Rasmani Astuti, 2011:101-102) }\end{array}$ & Tidak diceritakan \\
\hline Latar Restoran Barat. & $\begin{array}{l}\text { Songlian meminta Chen Zuoqian untuk } \\
\text { menemuinya di Restoran Barat saat pada pertemuan } \\
\text { pertama mereka. (Su Tong, diterjemahkan oleh } \\
\text { Rasmani Astuti, 2011:17) }\end{array}$ & Tidak diceritakan \\
\hline Tokoh Pemuda Ketiga Gu/ Tuan Muda Gu & $\begin{array}{l}\text { Feipu membawa temannya, yakni Pemuda Ketiga } \\
\text { Gu untuk mengajari Teratai bermain seruling. ( } \mathrm{Su} \\
\text { Tong, diterjemahkan oleh Rasmani Astuti, 2011:38) }\end{array}$ & Tidak diceritakan \\
\hline
\end{tabular}

\section{Penambahan}

Penambahan dalam film Raise the Red Lantern terdapat dalam aspek pengembangan latar dan sebagian besarnya mencakup penambahan peristiwa. Hal ini dilakukan agar cerita lebih terkesan dramatis sehingga dapat menarik minat penonton. Walaupun terdapat berbagai penambahan, namun inti cerita dari novel Raise the Red Lantern tidak berubah. Berikut tabel yang menunjukkan penambahan novel Raise the Red Lantern ke film Raise the Red Lantern.

Tabel 6. Tabel Penambahan Novel Raise the Red Lantern ke Film Raise the Red Lantern.

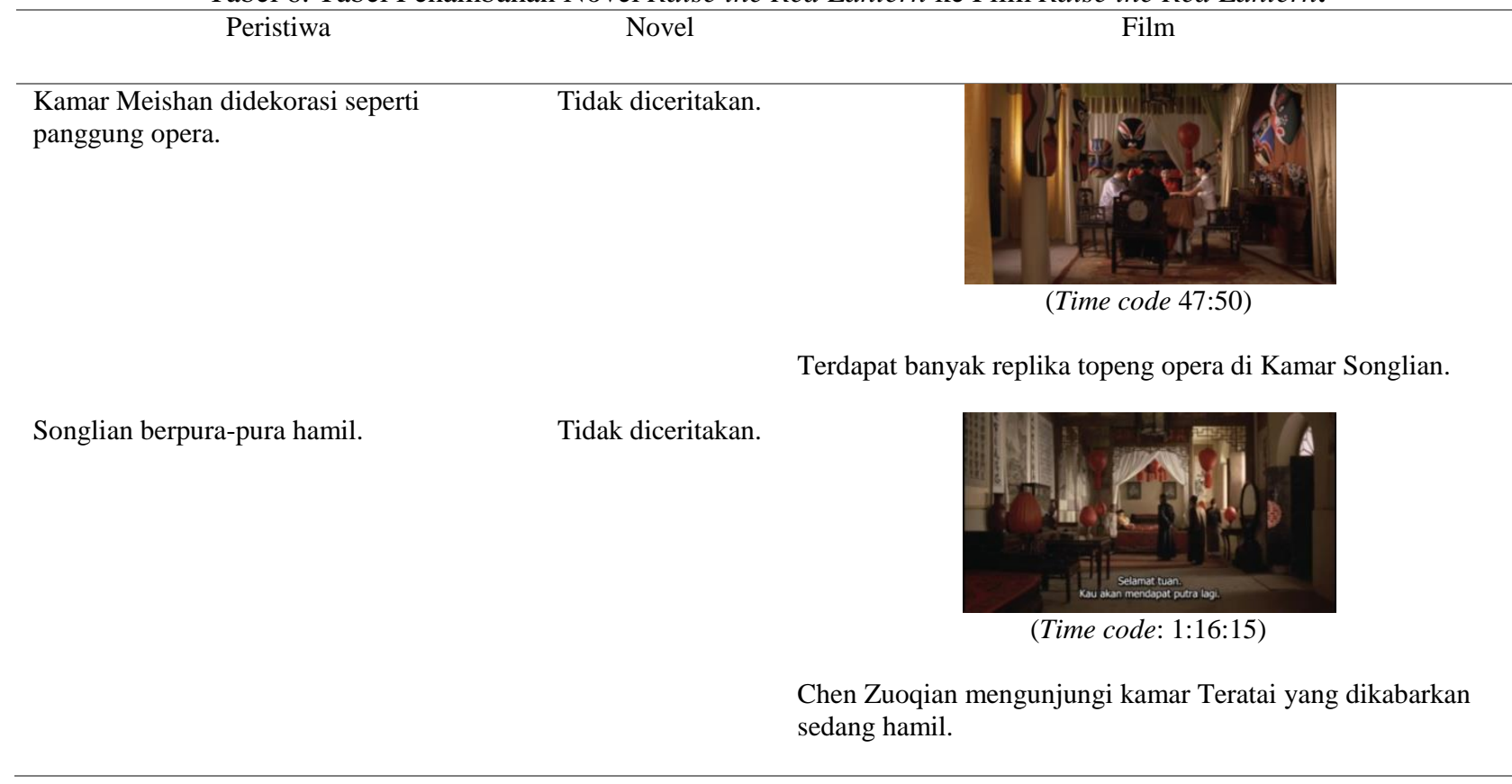




\begin{tabular}{|c|c|c|}
\hline Peristiwa & Novel & Film \\
\hline Lampion merah dan pijatan kaki. & Tidak diceritakan & 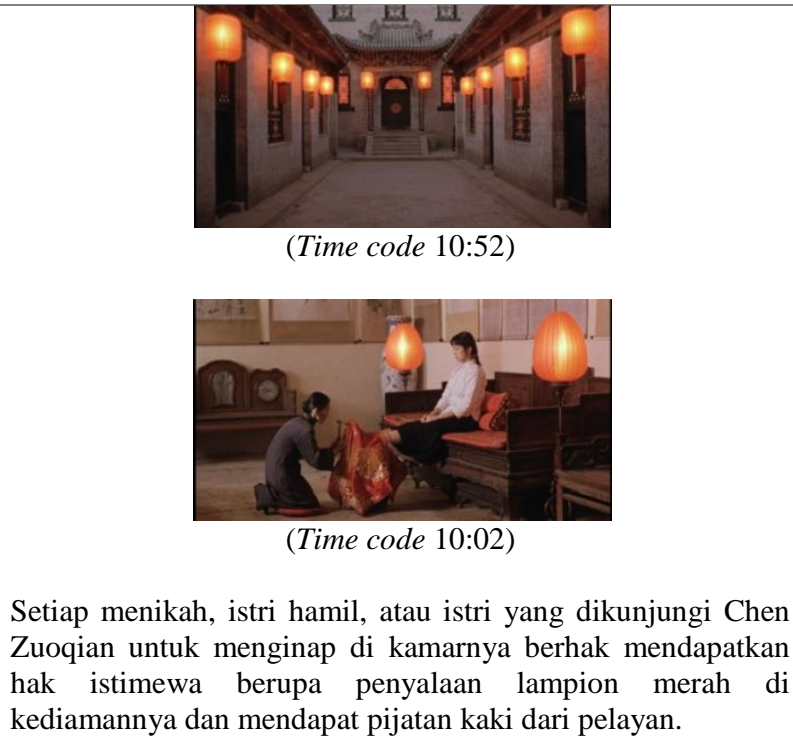 \\
\hline $\begin{array}{l}\text { Tradisi para istri berkumpul di halaman } \\
\text { rumah menunggu pegumuman dimana } \\
\text { Tuan Besar akan menginap. }\end{array}$ & Tidak diceritakan & $\begin{array}{l}\text { (Time code: 29:32) } \\
\text { Keempat istri Chen Zuoqian berkumpul di halaman rumah } \\
\text { untuk menunggu pengumuman di kediaman istri manakah } \\
\text { Chen Zuoqian akan menginap malam itu. }\end{array}$ \\
\hline
\end{tabular}

Sumber: Novel Raise the Red Lantern dan film Raise the Red Lantern

\section{Perubahan Bervariasi}

Perubahan bervariasi pada film tidak mempengaruhi substansi cerita terlalu jauh, melainkan tetap dapat mempertahankan inti cerita dalam novel. Pengubahan dilakukan agar alur ceita lebih menarik sehingga dapat menarik minat penonton. Berikut tabel yang menunjukkan perubahan bervariasi novel Raise the Red Lantern ke film Raise the Red Lantern.

Tabel 7. Tabel Perubahan Bervariasi Novel Raise the Red Lantern ke film Raise the Red Lantern.

\begin{tabular}{ll}
\hline \multicolumn{1}{c}{ Peristiwa } & \multicolumn{1}{c}{ Novel } \\
\hline Cara Songlian datang ke & Songlian datang ke kediaman \\
kediaman Chen & Chen dengan diusung tandu. (Su \\
& Tong, diterjemahkan oleh \\
& Rasmani Astuti, 2011:5)
\end{tabular}

Terbongkarnya perselingkuhan Meishan/ Karang.
Mega mengetahui sendiri perselingkuhan Karang dengan seorang dokter dan menangkap basah mereka di dalam kamar hotel. (Su Tong, diterjemahkan oleh Rasmani Astuti, 2011:131)
Film

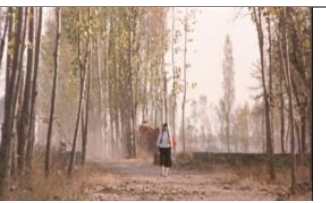

(Time code 2:38)

Songlian tidak menaiki tandu pernikahan yang dikirim Chen Zuoqian dan memilih berjalan kaki ke kediaman Chen.

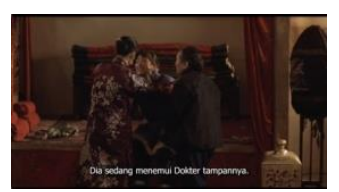

(Time code 1:44:34)

Songlian yang sedang mabuk tidak sengaja membeberkan perselingkuhan Songlian di depan Zhuoyun dan pelayan. 


\begin{tabular}{ll}
\hline \multicolumn{1}{c}{ Peristiwa } & \multicolumn{1}{c}{ Novel } \\
\hline $\begin{array}{l}\text { Lama masa studi Teratai/ } \\
\text { Songlian di perguruan tinggi. }\end{array}$ & $\begin{array}{l}\text { Teratai kuliah selama 1 tahun. (S } \\
\text { Tong, diterjemahkan oleh } \\
\text { Rasmani Astuti, 2011:15-16) }\end{array}$ \\
& \\
& \\
& \\
$\begin{array}{l}\text { Latar tempat saat Teratai/ } \\
\text { Songlian diperkenalkan } \\
\text { kepada Sukacita/ Yuru. }\end{array}$ & $\begin{array}{l}\text { Teratai sedang berada di kapel } \\
\text { Buddha saat Chen Zuoqian } \\
\text { memperkenalkan Sukacita } \\
\text { kepadanya. (Su Tong, } \\
\text { diterjemahkan oleh Rasmani }\end{array}$ \\
& Astuti, 2011:9)
\end{tabular}
Hukuman untuk istri yang
berselingkuh.

Sebab meninggalnya Walet/ Yan'er.

Adegan dengan latar belakang ruang tamu.
Walet meninggal karena sakit tifus setelah dihukum Teratai untuk memakan kertas toilet yang berisi guna-guna untuknya. ( $\mathrm{Su}$ Tong, diterjemahkan oleh Rasmani Astuti, 2011:104, $105,114)$

Karang yang berselingkuh dihukum dengan diceburkan ke dalam sumur. (Su Tong, diterjemahkan oleh Rasmani Astuti, 2011:131)
Songlian bercerita pada Zhuoyun bahwa dirinya pernah mengenyam bangku kuliah selama setengah tahun.

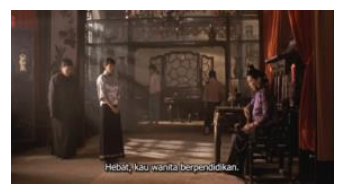

(Time code 19:32)

Songlian diajak oleh pelayan untuk menyapa dan memperkenalkan diri kepada Yuru di kediamannya.

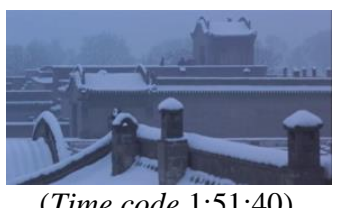

Meishan berselingkuh dengan Dokter Gao dan dihukum gantung di sebuah kamar kecil di atap rumah.

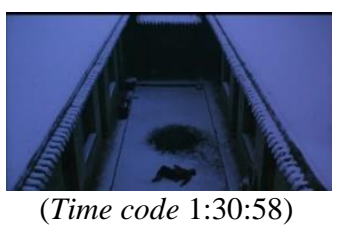

Yan'er meninggal karena sakit setelah dihukum berlutut di tengah hujan salju.

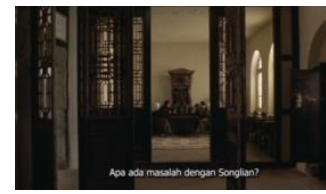

(Time code 1:25:24)

Dokter Gao menjelaskan hasil pemeriksaan kehamilan Songlian kepada Chen Zuoqian.

\section{KESIMPULAN}

Berdasarkan hasil analisis mengenai perbandingan unsur-unsur intrinsik penceritaan pada penelitan dengan judul "Perbandingan Novel Raise the Red Lantern dan Film Raise the Red Lantern" dapat ditarik kesimpulan sebagai berikut.
Pertama, berdasarkan hasil analisis perbandingan dari 2 objek material berupa novel Raise the Red Lantern dan film Raise the Red Lantern ditemukan adanya persamaan dan perbedaan, serta perubahan. Pada aspek penciutan, terdapat penghilangan sifat tokoh Feipu yang takut terhadap wanita dan memiliki ketertarikan khusus kepada laki-laki, penghilangan tokoh Tuan Muda Gu, penghilangan peristiwa Chen 
Zuoqian yang impoten, dan penghilangan beberapa latar tempat seperti ruang tamu, toilet, dan Restoran Barat.

Kedua, proses alih wahana berupa penambahan. Penambahan yang paling menonjol pada film Raise the Red Lantern adalah pemunculan konsep lentera merah pada tradisi keluarga Chen. Selain hal tersebut, terdapat pula penambahan peristiwa baru, yakni Songlian berpura-pura hamil, serta penambahan gambaran kamar Meishan yang didekorasi seperti panggung opera.

Ketiga, proses alih wahana berupa perubahan bervariasi. Perubahan bervariasi dari novel Raise the Red Lantern ke film Raise the Red Lantern terjadi pada aspek latar tempat, tokoh dan deskripsi peristiwa. Perubahan bervariasi pada aspek latar tempat sekaligus tokoh terdapat pada peristiwa saat Teratai/ Songlian diperkenalkan kepada Sukacita/ Yuru. Pada novelnya, Chen Zuoqian mengantarkan Songlian menemui Sukacita di kapel Buddha, sedangkan di dalam film Songlian diantar oleh pelayan untuk menemui Yuru di kediamannya. Sementara itu, perubahan banyak terjadi pada aspek peristiwa. Peristiwa-peristiwa tersebut yakni cara Songlian datang ke kediaman Chen, penyebab terbongkarnya perselingkuhan Meishan/ Karang, hukuman untuk istri yang berselingkuh, lama masa studi Teratai/ Songlian di perguruan tinggi, dan sebab meninggalnya Walet/ Yan'er.

Proses ekranisasi tentu akan menyebabkan berbagai perubahan dari karya aslinya. Perubahan tersebut bisa berupa penciutan, penambahan, serta perubahan bervariasi. Perubahan ini terjadi karena berbagai alasan seperti keterbatasan waktu dan alat, faktor kreativitas penulis skenario dan sutradara, maupun perubahan yang dilakukan untuk tujuantujuan tertentu. Tujuan-tujuan tersebut antara lain yaitu: 1) penciutan karakter Feipu yang takut terhadap wanita dan memiliki ketertarikan khusus kepada laki-laki untuk memfokuskan cerita film yang membahas mengenai nasib wanita dalam keluarga yang menerapkan poligami dalam sistem patriarki. 2) berbagai penambahan dan perubahan bervariasi yang bertujuan untuk menampilkan lebih banyak dinamika wanita-wanita yang tinggal di dalam kediaman Chen. Walau begitu, ekranisasi tidak merubah inti cerita dari karya novel yang diadaptasinya

\section{REFERENSI}

[1] M. Rahadiyanti, "Landasan Konseptual Perencanaan dan Perancangan Pusat Apresias Sastrai di Yogyakarta," Universitas Atma Jaya Yogyakarta, Yogyakarta, 2013.

[2] S. D. Damono, Alih Wahana, Jakarta: Gramedia Pustaka Utama, 2018.

[3] N. Huda, "Pengawasan Pelayanan Publik oleh Ombudsman," Universitas Andalas, Padang, 2010.

[4] B. Nurgiyantoro, Teori Pengkajian Fiksi, Yogyakarta : Gadjah Mada University Press, 2015.

[5] P. Eneste, Novel dan Film, Flores: Nusa Indah, 1991.

[6] J. Wicks, "Cinema," Berkshire Encyclopedia of China, vol. 5, p. 266, 2009.

[7] 尹鸿和凌燕, 新中国电影史, 长沙: 湖南美术 出版社, 2002. 